ALMEIDA, Larisse Macêdo de. Mediação e competência em informação: percepção da Comissão de Educação de Usuários do Sistema de Bibliotecas da UFC. 2019. 124 f. Dissertação (Mestrado em Ciência da Informação) - Universidade Federal do Ceará, Fortaleza, 2019.

\title{
MEDIAÇÃO E COMPETÊNCIA EM INFORMAÇÃO: percepção da Comissão de Educação de Usuários do Sistema de Bibliotecas da UFC
}

MEDIATION AND INFORMATION LITERACY: perception of the User Education Commission of the Library System of the UFC

\section{RESUMO}

No ambiente universitário a biblioteca possui importante papel na formação dos discentes como indivíduos críticos, autônomos e com habilidades voltadas para o acesso e apropriação da informação. Nesse contexto, as ações de mediação do bibliotecário devem possibilitar sua interferência no processo de aquisição da informação visando a apropriação da mesma para possibilitar a construção do conhecimento do usuário. Assim, nosso objetivo consiste em analisar a percepção, sobre a mediação e competência em informação, dos bibliotecários no processo de construção do conhecimento científico no ambiente universitário. Trata-se de uma pesquisa de abordagem qualitativa, com uso do método exploratório. Os dados coletados a partir de questionários e entrevista realizados com bibliotecários que atuam na Comissão de Educação de Usuários do sistema de bibliotecas da Universidade Federal do Ceará foram analisados pela técnica de análise de conteúdo a partir do estabelecimento de categorias. Com isso, verificamos que a distinção entre o conceito de habilidade e competência não está internalizada na compreensão dos bibliotecários, necessitando ser abordada com maior profundidade pois, mesmo ambas sendo colocadas em prática cotidianamente, essa lacuna acaba não permitindo que associem a competência ou habilidade específica a uma atividade particular. Os profissionais compreendem a essência dos conceitos de mediação e competência em informação, mas não explicitam o entrelaçamento das temáticas. Ainda assim, a Comissão busca alinhar constantemente seu planejamento com as necessidades dos usuários, destarte, concluímos que o desenvolvimento das atividades da Comissão vem contribuindo para a consolidação da cultura de pesquisa no ambiente acadêmico.

Palavras-chave: Mediação da Informação. Competência em Informação. Biblioteca Universitária. Profissional Bibliotecário. 


\begin{abstract}
In the university environment, the library has an important role in the training of students as critical individuals, autonomous and with skills focused on access and appropriation of information. In this context, the mediation actions of the librarian should enable their interference in the information acquisition process aiming at the appropriation of the information to enable the construction of the user's knowledge. Thus, our objective is to analyze the perception, mediation and information competence, of the librarians in the process of construction of scientific knowledge in the university environment. This is a qualitative research, using the exploratory method. The data collected from questionnaires and interviews conducted with librarians who work at the User Education Committee of the library system of the Federal University of Ceará were analyzed by the technique of content analysis from the establishment of categories. Thus, the distinction between the concept of ability and competence is not clear and definite among librarians, even though they are put into practice on a daily basis, which does not allow them to associate the specific competence or ability to a particular activity. The professionals understand the essence of the concepts of mediation and information competence, but do not explain the intertwining of the themes. Nevertheless, the Commission is constantly seeking to align its planning with the needs of its users. Therefore, we conclude that the development of the Commission's activities has contributed to the consolidation of the research culture in the academic environment.
\end{abstract}

Keywords: Mediation of information. Information Literacy. University Library. Librarian.

\title{
SOBRE A AUTORA
}

\section{Larisse Macêdo de Almeida}

Mestra em Ciência da Informação pelo Programa de Pós-Graduação em Ciência da Informação da Universidade Federal do Ceará (UFC).

E-mail: lari.biblio@yahoo.com.br.

\section{A ACESSO ABERTO}

Copyright: Esta obra está licenciada com uma Licença Creative Commons Atribuição 4.0 Internacional. (cc) $\mathrm{BY}$

Financiamento: Não

Recebido em: 04/06/2019.

Aceito em: 04/06/2019.

Revisado em: 04/06/2019.

Como citar este resumo:

ALMEIDA, Larisse Macêdo de. Mediação e competência em informação: percepção da Comissão de Educação de Usuários do Sistema de Bibliotecas da UFC. Informação em Pauta, Fortaleza, v. 4, n. 1, p. 9192, jan./jun. 2019. DOI: https://doi.org/10.32810/2525-3468.ip.v4i1.2019.41295.91-92. 